\title{
PERFORMANCE OF SOME SUGAR BEET VARIETIES UNDER DIFFERENT SOWING DATES
}

\author{
Al-Labbody A.H.S.A. \\ Sugar Crops Res. Inst., Agric. Res. Center, Giza, Egypt
}

\begin{abstract}
Two field experiments were conducted at Sakha, Kafer ElSheikh, Governorate in 2009/2010 and 2010/2011 seasons to evaluate five multigerm sugar beet varieties sown at three sowing dates $\left(1^{\text {st }}\right.$ September, $1^{\text {st }}$ October and $1^{\text {st }}$ November). The tested sugar beet varieties were imported from Germany (Del 937 and Carolla), France (LP13), Netherlands (Samba) and Sweden (Baraca). Split plot design with four replicates was applied in both seasons. Sowing dates were arranged in the main plots and varieties in the sub plots. The results indicated that sowing sugar beet on the $1^{\text {st }}$ of October significantly surpassed the other two dates in root length, diameter and fresh weight, sucrose $\%$ as well as root and sugar yields/fed., while impurities $\%$ in roots $(\alpha-$ amino $\mathrm{N}, \mathrm{K}$ and $\mathrm{Na} \%$ ) were increased by delaying sowing date up to the $1^{\text {st }}$ of November in both seasons. The tested sugar beet varieties differed significantly in root length, diameter and fresh weight, sucrose \%, root and sugar yields/fed., and impurities\% in both seasons. Carolla variety was the best one where it gave the highest root and sugar yields/fed. The interaction between the three sowing dates and five varieties had a significant effect on sucrose $\%$, root and sugar yields. Sowing Carolla variety on the $1^{\text {st }}$ October was recommended for cultivation in Kafer EL-Sheikh as it gave the highest sucrose\%, as well as sugar and root yields/fed in both seasons.
\end{abstract}

\section{Key words: Sugar beet varieties under different sowing dates.}

\section{INTRODUCTION}

There are many factors affecting yield and quality of sugar beet as nutritional status as well as some agro practices applications, such as sowing dates and methods. Allam et al (2005) showed that the highest values of root and sugar yields were obtained when sugar beet was sown on the $1^{\text {st }}$ of October. Ismail et al. (2006) found that early sowing date on $1^{\text {st }}$ October led to a significant increase in root fresh weight, sucrose $\%$, purity\%, sugar and root yields/fed compared with late sowing date on $15^{\text {th }}$ October and $1^{\text {st }}$ November. ElGeddawy et al. (2007) showed that sowing sugar beet early on $15^{\text {th }}$ September significantly attained the higher root length, diameter, root fresh weight/plant as well as root and sugar yields/fed than late sowing date on $15^{\text {th }}$ October. Mosa (2009) cleared that early sowing on $15^{\text {th }}$ September significantly increased root length, diameter, root and sugar yields/fed as compared with late sowing on $15^{\text {th }}$ October or November. El-Hosry et al. (2010) revealed that root length and root yield/fed were significantly larger with sowing on $15^{\text {th }}$ October as compared to $15^{\text {th }}$ Sepember and $15^{\text {th }}$ November.

All sugar beet genotypes cultivated in Egypt were imported from foreign countries, so, it is preferable to evaluate them under Egyptian conditions especially under different sowing dates to select the best ones characterized with high yield and quality traits. Osman (2005) evaluated some sugar beet varieties and observed that Toro significantly surpassed Pleno variety in root diameter, root fresh weight, top and root yields/fed. Aly (2006) found that Marathon

Fayoum J. Agric. Res. \& Dev., Vol.26, No.1, January, 2012 
Al-Labbody_A.H.S.A.

variety significantly surpassed the other varieties in root length, diameter, fresh weight, root and sugar yields/fed, while, Kawemira variety was the best in sucrose \%, purity\%, extractable sugar\% and extractability\%. Ismail et al. (2006) and Allam et al. (2007) indicated that sugar beet genotypes significantly differed in growth, yield and quality characteristics. Farida and Gazella gave the highest values of root yields/fed, as well as, root fresh weight, sucrose \% and purity\%. Ismail et al. (2007) evaluated some sugar beet varieties (Gloria, Mont bianco, Carolla, Desprezpoly, LP 13, Pleno, Baraca, Shems, Farida and Samba) and found that varieties significantly differed in root length, diameter, sucrose $\%$, purity $\%$ as well as, root and sugar yields/fed. Montbianco variety surpassed the other varieties in growth, yield and quality traits. Shalaby $\boldsymbol{e t}$ al. (2008) tested twenty sugar beet varieties namely Demapoly, Carola, Tteri, Kawemira, Desprez poly N, B 2001, FD 9902, FD 9901, FD 0405, FD 4901, Meridio, Mahara, Desprez mono N, Anema, LP 11, LP 12, LP 13, LP 14, LP 15 and LP 16. They found that LP 15 variety significantly surpassed the other ones in root length, diameter, fresh weight, root and sugar yields/fed, while, LP 12 showed the superiority in sucrose, purity $\%$ and extractability\% compared with those showed by other sugar beet varieties. Soha (2010) studied some sugar beet genotypes, and recorded that Toro variety surpassed other genotypes in root length and diameter, as well as, fresh and weight/plant, root and sugar yields/fed, while Lp11 recorded the lowest results.

The objective of the present work was to find out the appropriate sowing date and the best sugar beet variety to obtain the maximum root and sugar yields/fed.

\section{MATERIALS AND METHODS}

This work was carried out in the experimental field of Agriculture Research Center at Sakha, Kafer El-Sheikh Governorate during 2009/2010 and 2010/2011 seasons to investigate the effect of three sowing dates on growth, yield and quality of five sugar beet varieties. The tested sugar beet varieties were imported from Germany (Del 937 and Carolla), France (LP13), Netherlands (Samba) and Sweden (Baraca). Sowing dates were $1^{\text {st }}$ September, $1^{\text {st }}$ October and $1^{\text {st }}$ November. Mean of temperature degree and relative humidity $\%$ are illustrated in Table (1).

Table 1. Mean of temperature degree and relative humidity percentage during two growing seasons at Kafer El-Sheikh.

\begin{tabular}{|c|c|c|c|c|c|c|c|c|c|c|c|c|}
\hline \multirow{3}{*}{ Months } & \multicolumn{6}{|c|}{ 2009-2010 season } & \multicolumn{6}{|c|}{ 2010-2011 season } \\
\hline & \multicolumn{3}{|c|}{ Temperature $\left({ }^{\circ} \mathrm{C}\right)$} & \multicolumn{3}{|c|}{$\begin{array}{c}\text { Relative humidity } \\
(\%)\end{array}$} & \multicolumn{3}{|c|}{$\begin{array}{c}\text { Temperature } \\
\left({ }^{\circ} \mathrm{C}\right)\end{array}$} & \multicolumn{3}{|c|}{$\begin{array}{c}\text { Relative humidity } \\
(\%)\end{array}$} \\
\hline & Max. & Min. & Aver. & Max. & Min. & Aver. & Max. & Min. & Aver. & Max. & Min. & Aver. \\
\hline September & 33.2 & 20.4 & 26.8 & 86 & 34 & 60.0 & 33.5 & 19.3 & 26.4 & 82 & 28 & 55.0 \\
\hline October & 32.1 & 18.4 & 25.2 & 85 & 31 & 58.0 & 31.8 & 18.3 & 25.1 & 81 & 27 & 54.0 \\
\hline November & 27.7 & 15.5 & 21.6 & 88 & 40 & 62.0 & 28.1 & 13.7 & 20.9 & 80 & 29 & 54.5 \\
\hline December & 22.4 & 9.3 & 15.9 & 80 & 36 & 58.0 & 21.2 & 8.2 & 14.7 & 81 & 36 & 58.5 \\
\hline January & 21.2 & 8.8 & 15 & 82 & 35 & 58.5 & 21.1 & 7.6 & 14.3 & 77 & 33 & 55.0 \\
\hline February & 23.8 & 8.6 & 16.2 & 85 & 35 & 60.5 & 21.0 & 6.9 & 13.9 & 86 & 35 & 60.5 \\
\hline March & 27.2 & 12.4 & 19.8 & 81 & 31 & 56.0 & 25.2 & 9.4 & 17.3 & 78 & 28 & 53.0 \\
\hline April & 29.7 & 13.1 & 21.4 & 80 & 23 & 51.5 & 30.1 & 13.0 & 21.5 & 76 & 24 & 50.0 \\
\hline May & 30.2 & 14.7 & 22.5 & 79 & 22 & 50.5 & 31.7 & 14.6 & 23.15 & 75 & 22 & 48.5 \\
\hline
\end{tabular}

Source: Agro-meteorological Station, Agric. Res. Center, Giza, Egypt.

Fayoum J. Agric. Res. \& Dev., Vol.26, No.1, January, 2012 
A Split plot in a randomized complete block design with four replicates was applied in both seasons. Sowing dates were applied in the main plots and varieties in the sub plots. The sub plot area was $21 \mathrm{~m}^{2}$ including six rows spaced $50 \mathrm{~cm}$ and $7 \mathrm{~m}$ long. Nitrogen fertilizer in the form of urea $(46.5 \% \mathrm{~N})$ was applied at the recommended rate $(80 \mathrm{~kg} \mathrm{~N} / \mathrm{fed})$ in two equal doses; after thinning and 30 days later. Potassium fertilizer was added after thinning in the form of potassium sulfate $\left(48 \% \mathrm{~K}_{2} \mathrm{O}\right)$ at the rate of $24 \mathrm{~kg} \mathrm{~K} \mathrm{~K}_{2} \mathrm{O} / \mathrm{fed}$, while phosphorus fertilizer was added during land preparation in the form of calcium super phosphate $\left(15.5 \% \mathrm{P}_{2} \mathrm{O}_{5}\right)$ at a rate of $30 \mathrm{~kg} \mathrm{P}_{2} \mathrm{O}_{5} / \mathrm{fed}$. Other agricultural practices required for growing sugar beet were carried out as usually practiced in the region.

\section{Recorded data}

Sugar beet plants of the three guarded rows were up-rooted, topped, weighed and a random sample of ten roots was taken from each sub- plot to determine:

1. Root growth characters:

- Root length.

- Root diameter.

- Root fresh weight/plant.

2. Juice quality characteristics:

- Sucrose \% was polarimetrically determined at the laboratory according to the methods of Le-Docte (1927).

- Impurities\%: $\alpha$ - amino $\mathrm{N}, \mathrm{Na}$ and $\mathrm{K} \%$ in root fresh matter weight were determined using Flame Photometer at the laboratory as described by Page (1982), while $\alpha$ - amino $\mathrm{N} \%$ was determined according to the method of Carruthers et al. (1962).

3. Yields (ton/fed).

- Root yield ( $\mathrm{t} / \mathrm{fed})$.

- Theoretical sugar yield was calculated by multiply root yield $(\mathrm{t} / \mathrm{fed}) \mathrm{x}$ sucrose $\%$.

All collected data were statistically analyzed according to the procedures used by Snedecor and Cochran (1981).

\section{RESULTS AND DISCUSSION}

Effect of sowing date:

1. Root growth characters (length, diameter and fresh weight/plant)

Data in Table 2 clear that root growth characters were significantly affected by sowing dates variation in two seasons. October $1^{\text {st }}$ sowing date surpassed the other two sowing dates in root length and root fresh weight/plant, while, sowing sugar beet on $1^{\text {st }}$ September was the best for root diameter. These results may be attributed to favorable conditions prevailed during the early growth stage of seedlings that could boost their growth. Similar results were recorded by Allam et al. (2005), Ismail et al. (2006), El-Geddawy et al. (2007), Mosa (2009) and El-Hosry et al. (2010).

\section{Juice quality:}

\subsection{Sucrose\%}

Data in Table 2 clear that the studied sowing dates significantly affected sucrose $\%$ in $1^{\text {st }}$ and $2^{\text {nd }}$ seasons. The early sowing on $1^{\text {st }}$ September surpassed the other two sowing dates for sucrose\%, where the high mean value was (17.33 and 15.66) in both seasons. These results may be attributed to the suitable conditions

Fayoum J. Agric. Res. \& Dev., Vol.26, No.1, January, 2012 
at harvest as a result to early sowing where the temperature degree at harvest in on March encouraged the accumulation of sucrose in root\%. Data also showed insignificant differences between sowing beets on $1^{\text {st }}$ September and $1^{\text {st }}$ October for sucrose\%. Similar results were evidenced by Allam et al. (2005), Ismail $\boldsymbol{e t}$ al. (2006), El-Geddawy et al. (2007), Mosa (2009) and El-Hosry et al. (2010).

\subsection{Impurities\% ( $\alpha$ - amino $\mathrm{N}, \mathrm{Na}$ and $\mathrm{K} \%$ )}

Data illustrated in Table 2 clear that the three sowing dates significantly differed in their effects on impurities $\%$ in two seasons. $1^{\text {st }}$ October sowing date was the best where it gave the lowest impurities\% than other two sowing dates. The lowest mean values were (1.36 and 1.12) for $\alpha$ - amino $\mathrm{N},(1.06$ and 0.88$)$ for $\mathrm{Na} \%$ and (1.72 and 1.10) for $\mathrm{K} \%$ in both seasons, respectively. While, the late date on $1^{\text {st }}$ November attained the highest impurities $\%$ and the lowest sucrose $\%$. These results may be attributed to unsuitable conditions at harvest, where, the maximum of temperature degree and relative humidity which led to sucrose analysis and hence decrease in sucrose $\%$ and increase in impurities \%. Theses results coincide with those reported by Allam et al (2005), Ismail et al. (2006), El-Geddawy et al. (2007), Mosa (2009) and El-Hosry et al. (2010).

Table 2: Effect of sowing dates on roots growth, quality\% and yields (t/fed) at harvest.

\begin{tabular}{|c|c|c|c|c|c|c|c|c|c|}
\hline \multirow[b]{2}{*}{ Sowing dates } & \multicolumn{3}{|c|}{ Root growth characters } & \multirow[b]{2}{*}{$\begin{array}{c}\text { Sucrose } \\
(\%)\end{array}$} & \multicolumn{3}{|c|}{ Impurities (\%) } & \multicolumn{2}{|c|}{ Yields (t/fed) } \\
\hline & $\begin{array}{c}\text { Length } \\
\text { (cm) }\end{array}$ & $\begin{array}{l}\text { Diameter } \\
\text { (cm) }\end{array}$ & $\begin{array}{c}\text { Fresh } \\
\text { weight } \\
\text { /plant (kg) }\end{array}$ & & $\alpha-\operatorname{aminoN}$ & $\mathrm{Na}$ & $\mathbf{K}$ & Root & Sugar \\
\hline \multicolumn{10}{|c|}{ 2009/2010 season } \\
\hline $\mathbf{1}^{\text {st }}$ Sept. & 27.43 & 13.30 & 0.90 & 17.33 & 1.76 & 1.77 & 2.00 & 28.44 & 4.93 \\
\hline $1^{\text {st }}$ Oct. & 30.89 & 12.75 & 1.01 & 16.97 & 1.36 & 1.06 & 1.72 & 30.76 & 5.22 \\
\hline $1^{\text {st }}$ Nov. & 24.75 & 11.71 & 0.85 & 15.70 & 2.10 & 1.88 & 2.44 & 25.94 & 4.07 \\
\hline LSD $5 \%$ & 1.12 & 0.85 & 0.11 & 0.94 & 0.45 & 0.53 & 0.39 & 1.75 & 0.77 \\
\hline \multicolumn{10}{|c|}{$2010 / 2011$ season } \\
\hline $1^{\text {st }}$ Sept. & 28.00 & 14.45 & 0.81 & 15.66 & 1.88 & 1.43 & 2.24 & 26.14 & 4.09 \\
\hline $1^{\text {st }}$ Oct. & 33.64 & 13.10 & 1.29 & 14.92 & 1.12 & 0.88 & 1.10 & 28.46 & 4.25 \\
\hline $1^{\text {st }}$ Nov. & 25.00 & 12.15 & 0.79 & 13.66 & 2.20 & 1.65 & 2.70 & 23.66 & 3.23 \\
\hline LSD $5 \%$ & 2.10 & 0.79 & 0.09 & 0.77 & 0.38 & 0.21 & 0.25 & 0.66 & 0.23 \\
\hline
\end{tabular}

Impurities \%, N= Nitrogen, $\mathrm{Na}=$ Sodium, $\mathrm{K}=$ Potassium.

\section{Root and sugar yields/fed:}

Data in Table 2 show that sowing dates had significant different effect on root and sugar yield/fed in $1^{\text {st }}$ and $2^{\text {nd }}$ season. Sowing sugar beet on $1^{\text {st }}$ October, the highest mean values of root and sugar yields in both seasons. This result could be attributed to the increase in yield components in the middle sowing date $\left(1^{\text {st }}\right.$ October) and hence root and sugar yields. On the contrary, the late sowing date on $1^{\text {st }}$ November led to the exposure of plant tops to hot weather and high temperature degrees by the end of the growing season, which increased transpiration rate and dehydration of leaves and in turn decreased root yield. These results are in line with those reported by Allam et al (2005), Ismail et al (2006), El-Geddawy et al (2007), Mosa (2009) and El-Hosry et al (2010).

\section{Differences among the evaluated sugar beet varieties:}

1. Root growth characters (length, diameter and fresh weight/plant)

Data in Table 3 show that the five varieties differed significantly in root growth characters in both seasons. Carolla variety surpassed the other varieties in all traits where, it produced the highest root length, root diameter and root fresh weight in both seasons, followed by Samba and Baraca. While, LP 13 recorded

Fayoum J. Agric. Res. \& Dev., Vol.26, No.1, January, 2012 
the lowest values in root length, diameter and fresh weight as compared with Carolla or Samba only. The differences among the tested sugar beet varieties in these traits might be due to the differences in their gene make up. These findings are in agreement with those obtained by Ismail et al. (2006), Allam et al. (2007), Ismail et al. (2007), Shalaby et al. (2008) and Soha (2010).

\section{Juice quality:}

\subsection{Sucrose\%}

Data in Table 3 show that the five sugar beet varieties differed significantly in sucrose\% in both seasons. Carolla variety gave the highest value of sucrose \% compared to the other varieties followed by Samba and Baraca, while, LP 13 gave the lowest values of this trait in both seasons. These results may be due to the variation in the genetic structure of the evaluated genotypes. These results are in agreement with those obtained by Ismail $\boldsymbol{e t}$ al. (2006), Allam et al. (2007), Ismail et al. (2007), Shalaby et al. (2008) and Soha (2010).

Table 3. Root growth, quality \% and yields (t/fed) at harvest of the tested sugar beet varieties.

\begin{tabular}{|c|c|c|c|c|c|c|c|c|c|}
\hline \multirow[b]{2}{*}{ Varieties } & \multicolumn{3}{|c|}{ Root growth characters } & \multirow[b]{2}{*}{$\begin{array}{c}\text { Sucrose } \\
(\%)\end{array}$} & \multicolumn{3}{|c|}{ Impurities (\%) } & \multicolumn{2}{|c|}{ Yields/fed (t) } \\
\hline & $\begin{array}{c}\text { Length } \\
\text { (cm) }\end{array}$ & $\begin{array}{l}\text { Diameter } \\
\text { (cm) }\end{array}$ & $\begin{array}{c}\text { Fresh weight } \\
\text { /plant (kg) }\end{array}$ & & $\begin{array}{c}\alpha- \\
\operatorname{aminoN}\end{array}$ & $\mathbf{N a}$ & $\mathbf{K}$ & Root & Sugar \\
\hline \multicolumn{10}{|c|}{ 2009/2010 season } \\
\hline Carolla & 29.25 & 13.23 & 1.18 & 18.60 & 1.46 & 1.31 & 2.06 & 30.20 & 5.62 \\
\hline Samba & 28.80 & 13.20 & 1.07 & 17.96 & 1.56 & 1.32 & 2.09 & 29.23 & 5.25 \\
\hline Baraca & 27.61 & 13.09 & 1.06 & 16.48 & 1.78 & 1.42 & 2.10 & 28.47 & 4.69 \\
\hline Del 937 & 26.75 & 12.40 & 0.99 & 15.67 & 1.85 & 1.70 & 2.11 & 27.83 & 4.36 \\
\hline LP 13 & 26.03 & 11.87 & 0.85 & 15.30 & 1.95 & 1.78 & 2.16 & 26.17 & 4.00 \\
\hline LSD $5 \%$ & 1.65 & 0.70 & 0.18 & 1.75 & 0.23 & 0.19 & 0.09 & 1.85 & 0.90 \\
\hline \multicolumn{10}{|c|}{$2010 / 2011$ season } \\
\hline Carolla & 32.60 & 14.56 & 1.13 & 16.53 & 1.67 & 1.22 & 2.23 & 27.93 & 4.62 \\
\hline Samba & 29.92 & 14.32 & 1.08 & 16.00 & 1.70 & 1.24 & 2.39 & 26.93 & 4.29 \\
\hline Baraca & 28.70 & 13.36 & 1.04 & 15.93 & 1.73 & 1.35 & 2.42 & 26.17 & 3.78 \\
\hline Del 937 & 27.24 & 12.79 & 0.99 & 14.43 & 2.23 & 1.46 & 2.45 & 25.53 & 3.47 \\
\hline LP 13 & 25.95 & 12.31 & 0.97 & 14.10 & 2.36 & 1.60 & 2.60 & 23.87 & 3.37 \\
\hline LSD $5 \%$ & 1.22 & 0.15 & 0.11 & 0.55 & 0.18 & 0.15 & 0.07 & 0.66 & 0.26 \\
\hline
\end{tabular}

Impurities\%, $\mathrm{N}=$ Nitrogen, $\mathrm{Na}=$ Sodium, $\mathrm{K}=$ Potassium.

\subsection{Impurities\% ( $\alpha$ - amino $\mathrm{N}, \mathrm{Na}$ and $\mathrm{K} \%$ ):}

Data in Table 3 show that varieties differed significantly in juice impurities\% ( $\alpha$ amino $\mathrm{N}, \mathrm{Na}$ and $\mathrm{K} \%$ ) in both seasons. Carolla variety was the best variety where, it had the lowest values of impurities\% in both seasons, while, LP 13 attained the highest values in impurities\% as compared with other varieties. The variation among genotypes in these characters could be attributed to the difference in their gene make-up. Similar results are obtained by Ismail $\boldsymbol{e t}$ al. (2006), Allam et al. (2007), Ismail et al. (2007), Shalaby et al. (2008) and Soha (2010).

\section{Root and sugar yields/fed:}

Data in Table 3 show that varieties differed significantly in root and sugar yields in both seasons. Carolla variety surpassed the other varieties, in root and sugar yields in both seasons, followed by Samba and Baraka, while, LP 13 attained the lowest values of these traits. These results may be due to the increase in yield components. These results coincide with those reported by Ismail et al

Fayoum J. Agric. Res. \& Dev., Vol.26, No.1, January, 2012 
(2006), Allam et al. (2007), Ismail et al. (2007), Shalaby et al. (2008) and Soha (2010).

\section{Interaction effects:}

Data in Table 4 clear that the interaction between the five sugar beet varieties and the three sowing dates affected significantly sucrose $\%$, sugar and root yields/fed in both seasons. Carolla variety sown in October $1^{\text {st }}$ gave the highest values of the studied traits compared to other combinations, while, LP 13 variety sown on November $1^{\text {st }}$ recorded the lowest values

Table 4: The interaction between the tested sugar beet varieties and sowing dates at harvest

\begin{tabular}{|c|c|c|c|c|c|c|c|c|c|}
\hline \multirow{3}{*}{$\begin{array}{c}\text { Sugar beet } \\
\text { Varieties }\end{array}$} & \multicolumn{9}{|c|}{ Sowing dates } \\
\hline & $1^{\text {st }}$ Sept. & $1^{\text {st }}$ Oct. & $1^{\text {st }}$ Nov. & $1^{\text {st }}$ Sept. & $1^{\text {st }}$ Oct. & $1^{\text {st }}$ Nov. & $\mathbf{1}^{\text {st }}$ Sept. & $1^{\text {st }}$ Oct. & $1^{\text {st }}$ Nov. \\
\hline & \multicolumn{3}{|c|}{ Sucrose (\%) } & \multicolumn{3}{|c|}{ Root yield/fed (t) } & \multicolumn{3}{|c|}{ Sugar yield/fed (t) } \\
\hline \multicolumn{10}{|c|}{$2009 / 2010$ season } \\
\hline Carolla & 18.68 & 19.77 & 17.36 & 30.80 & 32.30 & 27.50 & 5.75 & 6.39 & 4.77 \\
\hline Samba & 18.21 & 18.56 & 17.10 & 29.00 & 31.40 & 27.30 & 5.28 & 5.83 & 4.67 \\
\hline Baraca & 16.90 & 17.17 & 15.36 & 28.40 & 31.00 & 26.00 & 4.80 & 5.32 & 3.99 \\
\hline Del 937 & 15.57 & 16.99 & 14.45 & 28.10 & 30.40 & 25.00 & 4.38 & 5.16 & 3.61 \\
\hline LP 13 & 15.49 & 16.18 & 14.22 & 25.90 & 28.70 & 23.90 & 4.01 & 4.64 & 3.40 \\
\hline LSD $5 \%$ & & 1.35 & & & 1.80 & & & 0.75 & \\
\hline \multicolumn{10}{|c|}{$2010 / 2011$ season } \\
\hline Carolla & 16.60 & 17.70 & 15.30 & 28.50 & 30.00 & 25.20 & 4.73 & 5.31 & 3.86 \\
\hline Samba & 16.20 & 16.50 & 15.10 & 26.70 & 29.10 & 25.00 & 4.33 & 4.80 & 3.78 \\
\hline Baraca & 14.90 & 15.10 & 13.30 & 26.10 & 28.70 & 23.70 & 3.89 & 4.33 & 3.15 \\
\hline Del 937 & 13.50 & 14.90 & 12.40 & 25.80 & 28.10 & 22.70 & 3.48 & 4.19 & 2.81 \\
\hline LP 13 & 13.40 & 14.10 & 12.20 & 23.60 & 26.40 & 21.60 & 3.16 & 3.72 & 2.64 \\
\hline LSD $5 \%$ & & 1.13 & & & 1.80 & & & 0.65 & \\
\hline
\end{tabular}

\section{REFERENCES}

Allam, S.A.H.; K. El-Sh. Mohamed; G.S. El-Sayed and A.M.H. Osman (2005). Effect of sowing date, nitrogen fertilizer and row space on yield and quality of sugar beet crop. Annals of Agric. Sc., Moshtohor 43 (1): 11-24.

Allam, S.M.; N.M.S. Shalaby and A.H.S. Al-Labbody (2007). Yield and quality of ten sugar beet varieties grown in two locations. Egypt. J. Plant Breed. 11 (3): 111-134.

Aly. E.F. (2006). Effect of environmental conditions on productivity and quality of some sugar beet varieties. Ph.D. Thesis, Fac. Agric. Benha. Univ., Egypt.

Carruthers, A.; J.F.T. Oldfield and H.J. Teague (1962). Methods for assessment of beet quality. $15^{\text {th }}$ Annual Tech. Conf., British Sugar Corp. LTD. 36pp. (C.F. The Sugar Beet Crop Book, 572-573, $1^{\text {st }}$ Ed. published by Chapman and Hall, Univ. Press, Cambridge, UK.).

El-Geddawy, I.H.; M.S. Osman, G.A. Taha and S.A.A.M. Enan (2007). Transplanting using paper pots technique and nutrition with relation to yield and its attributes of sugar beet under different planting dates. Egypt. J. Agric. Res. 85 (1): 191-210.

El-Hosry, A.A.; M.I. Salwau; A.M.M. Saad; I.H. El-Geddawy and B.S. Ibrahim (2010). Sugar beet yield and its components as affected by

Fayoum J. Agric. Res. \& Dev., Vol.26, No.1, January, 2012 
PERFORMANCE OF SOME SUGAR BEET VARIETIES UNDER ....

sowing date, mineral $\mathrm{N}$ and bio fertilizers. Egypt. J. Appl. Sci. 25 (8A): 349-366.

Ismail, A.M.A.; A.H.S.A. Al-Laboody and N.M.S. Shalaby (2006). Variability and traits relationships in sugar beet under different sowing dates. Egypt. J. Plant Breeding 10 (1): 387-406.

Ismail, A.M.A.; A.H.S.A. Al-Laboody and N.M.S. Shalaby (2007). Evaluation of some sugar beet varieties under different combinations of NPK fertilizers. Egypt. J. Appl. Sci. 22 (3): 77-90.

Le-Docte, A. (1927). Commercial determination of sugar in the beet root using the sacks. Le-Docte Process. Int. Sug. J. 29: 488-492.

Mosa, D.T.M.A. (2009). Effect of sowing and harvesting dates on yield and quality of some sugar beet varieties. M.Sc. Thesis, Fac. Agric., Cairo Univ. Egypt.

Osman, M.S.H. (2005). Effect of $\mathrm{K}$ and $\mathrm{Mg}$ on yield and quality of two sugar beet varieties. Egypt. J. Agric. Res. 83 (1): 215-228.

Page, A.L. (1982). "Methods of Soil Analysis". Chemical and Microbiological Properties. $2^{\text {nd }}$ Ed., Agron. 9, Am. Soc. Agron. Inc. Publ. Madison, Wis, USA.

Shalaby, N.M.S.; A.H.S.A. Al-Labbody and S.R.E. El-Sheikh (2008). Covariability of yield and quality of twenty sugar beet genotypes. Egypt. J. Plant Breed. 12 (1): 267-277.

Snedecor, G.W. and Cochran, W.G. (1981). Statistical Method, $6^{\text {th }}$ Ed., Iowa State Univ., Press, Ames, Iowa, USA.

Soha, Khalil, R.A.E. (2010). Study of performance and behavior of some sugar beet varieties under different Environmental conditions. Ph.D. Thesis. Fac. Agric., Fayoum Univ., Egypt.

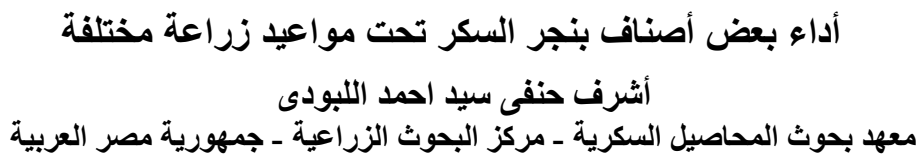

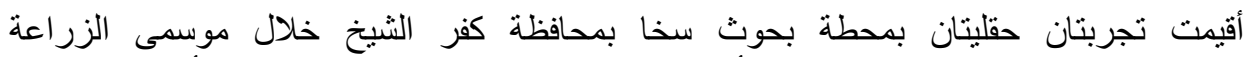

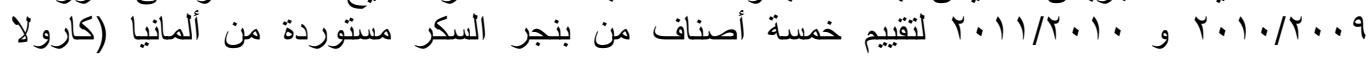

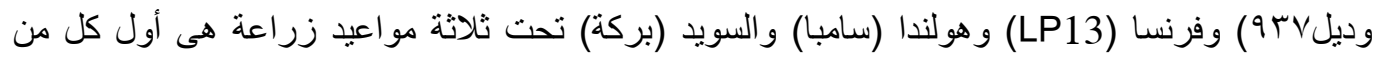

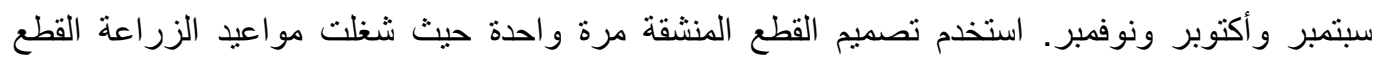

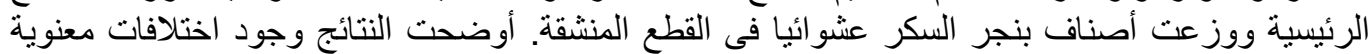

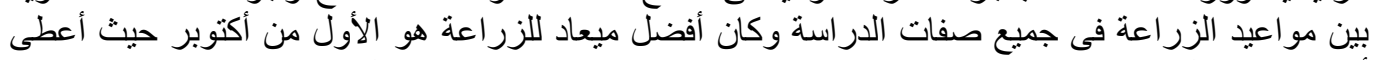

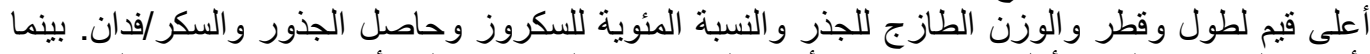

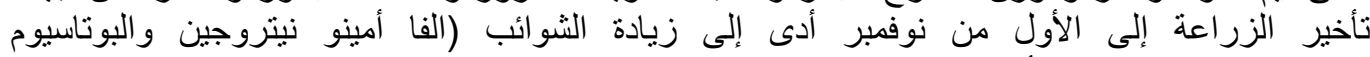

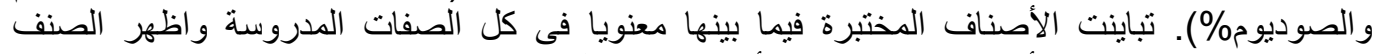

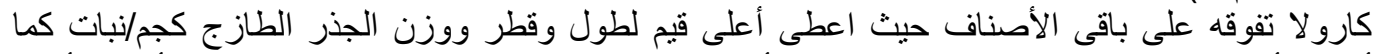

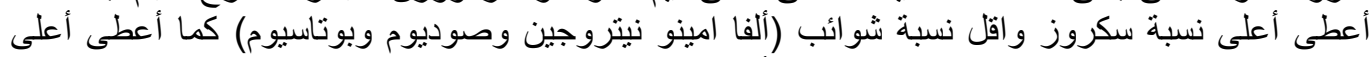

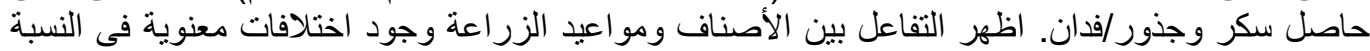

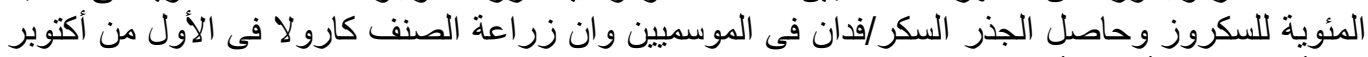

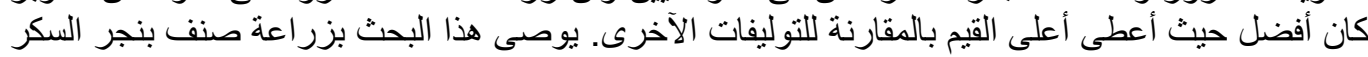

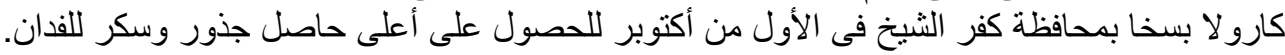

Fayoum J. Agric. Res. \& Dev., Vol.26, No.1, January, 2012 